\title{
Using EPM Model and GIS for Estimation of Soil Erosion in Souss Basin, Morocco
}

\author{
Argaz Ahmed ${ }^{1, a,}$, Darkaoui Adil ${ }^{1, b}$, Bikhtar Hasna ${ }^{1, c}$, Ayouch Elbachir ${ }^{2, d}$, Ramdan Lazaar $^{2, e}$ \\ ${ }^{1}$ Laboratory of Geography, Planning, Demography and Development, Faculty of Letters and Human Sciences, Ibn Zohr University, BP 29/S \\ 80000, Agadir, Morocco \\ ${ }^{2}$ Laboratory of geo development in arid and semi-arid regions, Faculty of Letters and Human Sciences, Ibn Zohr University, BP 29/S 80000, \\ Agadir, Morocco \\ *Corresponding author
}

\begin{tabular}{l|l}
\hline A R T I C L E I N F O & A B S T R A C T \\
\hline Research Article & $\begin{array}{l}\text { The study is aimed at predicting soil erosion and investigate its spatial distribution in Souss basin } \\
\text { area used EPM (erosion potential model), also known as Gavrilovic method, incorporating into GIS } \\
\text { (geographic information system) software. The spatial distribution of soil erosion shows three main } \\
\text { zones in the studied area (very slight, slight to moderate). The main factors in the EPM (soil } \\
\text { erodibility, soil protection, slope, temperature and rainfall) were evaluated using GIS software. Data } \\
\text { layers used in this study were created from digital elevation model (DEM), lithology maps, landsat } \\
8 \text { oli digital images, the highest amount of erosion occurred in the northeast regions, Results showed } \\
\text { that about } 87.84 \% \text { of the study area is classified in low and very low to destructive erosion intensify, } \\
12.15 \% \text { of the study area was moderate potential soil losses. }\end{array}$ \\
Accepted : $01 / 07 / 2019$ &
\end{tabular}

Keywords:

EPM model

GIS

Soil erosion

Souss basin

Morocco

$12.15 \%$ of the study area was moderate potential soil losses.

\section{Introduction}

Soil erosion by water occurs throughout the world. It is the process of detachment or entrainment, transportation of surface soil particles from original location and deposition of it to a new depositional area (Patil, 2018). Water erosion has been recognized as the most severe hazard threatening the protection of soil as it reduces soil productivity by removing the most fertile topsoil (FAO/UNEP, 1994).The detrimental impacts of soil erosion include decrease of effective root depth, nutrient and water imbalance in the root zone, and subsequent decrease in soil quality that leads to loss of fertile top soil cover and finally a reduction in agricultural production. It also delivers millions of tons of sediment into reservoirs and lakes, causes damages to the dams facilities, and results in high economic costs by affecting the water quality (Noori et al., 2016). Spatial and quantitative information on soil erosion on a watershed scale contributes significantly to the planning for soil conservation, erosion control, and management of the watershed environment (Prasannakumar et al., 2015). Soil erosion rate is controlled by natural factors such as intensify of rainfall, soil properties, topography, vegetation cover, catchment morphology, drainage network characteristics and land-use practices, as well as human activities (Reza et al., 2012).

There are several physical and empirical models that consider soil erosion in watersheds, these models vary from simple to more complex and differ in their need for data input and their ability to predict soil erosion by water (Chadli, 2016),A major problem concerning the modeling of erosion process with physically based models is the optimization of erosion parameters that cannot be directly measured in the field. Several optimization methods have been tested in the past during the calibration of such erosion models, but it is difficult to assure that the final values are not trapped in a local minimum, The most common empirical models to estimate soil erosion are the 
universal soil loss equation (USLE) method (Wischmeier and Smith, 1978), the water erosion prediction project (WEPP) method, the Pacific southwest interagency committee (PSIAC) method (Reza et al., 2012) and erosion potential method (EPM) (Gavrilovic, 1988).

In Morocco and especially in semi-arid regions, water erosion is a source of degradation. It is a major cause of desertification and siltation of potential dams (Elaloui et al., 2017), the choice of our watershed was dictated by its second most important economic region in Morocco, due mainly to its high-value agricultural production(ChoukrAllah et al., 2017) and its one of the most exposed Moroccan regions to erosion, The main objective of this current study is the mapping of water erosion at the Souss watershed applying the empirical model of soil loss
"EPM", The modeling was done by mapping the various factors as a platform of Geographic Information Systems and their superposition to develop a quantitative map of water erosion in $\mathrm{m}^{3} / \mathrm{km}^{2} /$ year.

\section{Materials and Methods}

\section{Study Area}

The Souss Basin is located in the middle western of Morocco, occupying a total surface of $17186 \mathrm{~km} 2$, which is approximately between 9.6-7.47o west longitudes and 29.70-31.11o north latitudes, The Anti-Atlas Mountains in the south, the High Atlas Mountains in the north, the Siroua massif in the east, and the Atlantic Ocean in the west are the natural limits of the Souss River Basin (Figure 1).

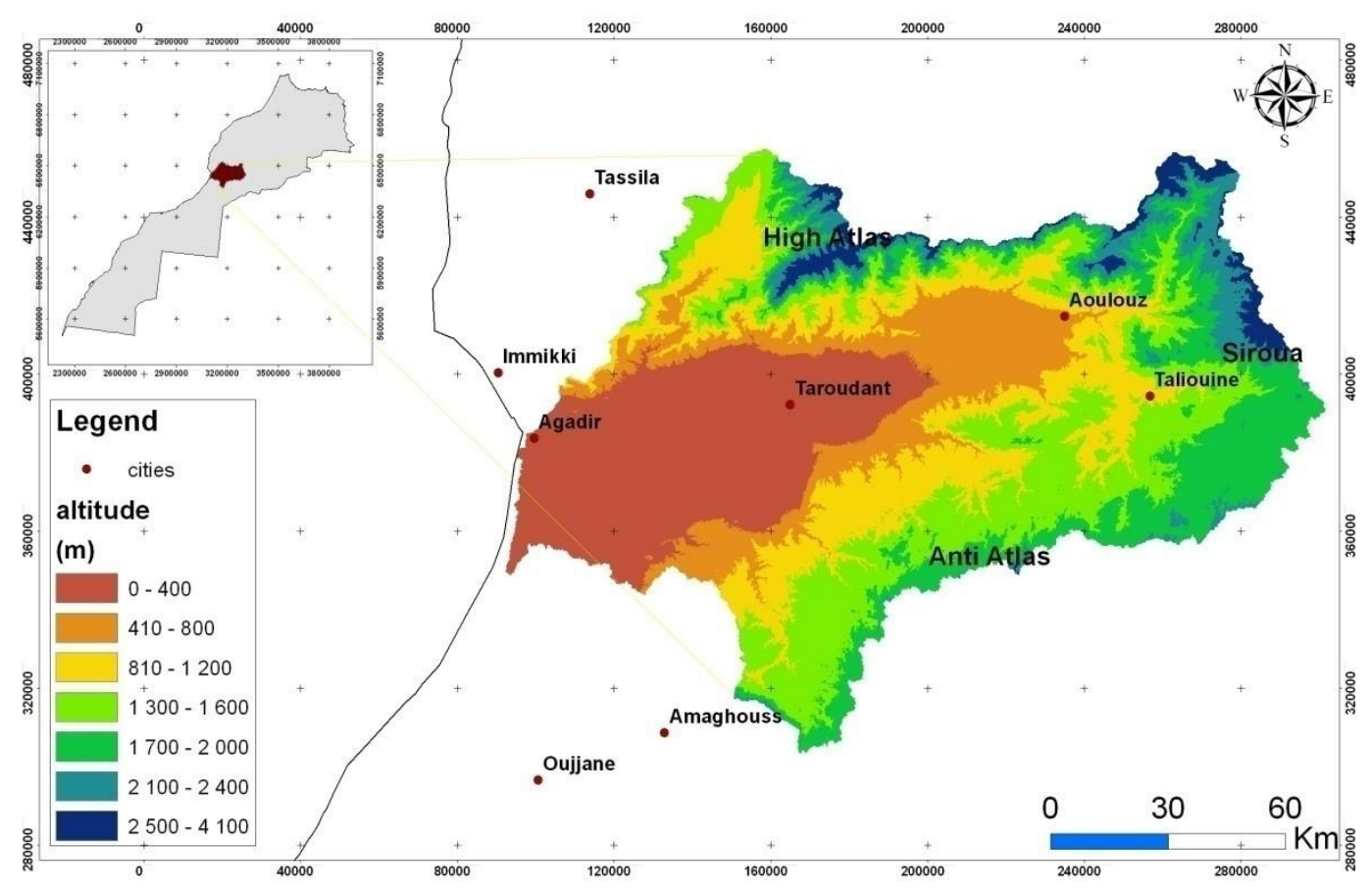

Figure 1 Location of study area

\section{The Erosion Potential Model (EPM)}

There are various methods that consider soil erosion in watersheds, these methods vary from simple to more complex and differ in their need for data input and their ability to predict erosion (Chadli, 2016), The Gavrilović model, also known as the Erosion Potential Model (EPM), was developed by Slobodan Gavrilović based on erosion field research in the Morava River catchment area in Serbia in the 1960`s, The method itself is based on the Method for the Quantitative Classification of Erosion (MQCE), formally developed in 1954 (Dragičević et al., 2016), EPM method gives a quantitative estimation of erosion intensity as well as the estimation of Sediment production and transportation (Yousefi and Mirzaee, 2014). Gavrilović (1988) proposed an analytical equation for determining the annual volume of detached soil due to surface erosion. The EPM is a model for qualifying the erosion severity and estimating the total annual sediment yield (Ali et al., 2016), According to the EPM method, the annual volume of detached soil due to surface erosion is calculated using the following equation(1):

$$
\mathrm{W}=\mathrm{T} \cdot \mathrm{H} \cdot \pi \cdot \sqrt{\mathrm{Z}^{3}}
$$

In which, $\mathrm{W}$ is the volume of soil erosion $\left(\mathrm{m}^{3} / \mathrm{km}^{2} /\right.$ year $), \mathrm{H}$ is the annual rainfall $(\mathrm{mm}), \mathrm{Z}$ is erosion intensity, and $\mathrm{T}$ is the coefficient of temperature which is calculated as shown in the following equation: (2):

$$
\mathrm{T}=\sqrt{\left(\frac{\mathrm{t}}{10}+0.1\right)}
$$

Where $\mathrm{t}$ is the mean annual temperature $\left({ }^{\circ} \mathrm{C}\right)$. The erosion coefficient $(Z)$ depends of four factors control erosion development (exposed rock and soil, topography, and vegetal cover/land use, which can be calculated as (3)

$$
\mathrm{Z}=\mathrm{Y} \cdot \mathrm{X}_{\mathrm{a}} \cdot(\psi+\sqrt{\mathrm{J}})
$$

Where $\mathrm{Y}$ is the soil erodibility coefficient, $\mathrm{Xa}$ is the soil protection coefficient, $\psi$ is the erosion and stream network development coefficient, $\mathrm{J}$ is the average slope of the watershed $(\%)$. 
The erosion coefficient $(\mathrm{Z})$ is presented classified as shown in Table 1 (Zemljic, 1971).

Table 1 Classification of $Z$ coefficient values

\begin{tabular}{l|c}
\hline \multicolumn{1}{c|}{ Erosion Intensity } & $\mathrm{Z}$ \\
\hline Very low & $<0.19$ \\
low & $0.20-0.40$ \\
Moderate & $0.41-.70$ \\
High & $0.71-1.00$ \\
Very High & $>1.00$ \\
\hline
\end{tabular}

\section{Results and Discussion}

\section{Soil Erodibility Coefficient $(Y$ factor)}

Lithology Coefficient influences geomorphology of an area by controlling erosional processes, as soil erodibility relies on it. As a consequence, it influences the speed of erosional processes (Ali et al., 2016), Soil erodibility coefficient (Y Factor) can be expressed as the inverse value of the resistance of soil to erosion due to the erosive force of precipitation (Efthimiou and Lykoudi, 2016). In this study, data for estimating the Soil Erodibility coefficient was obtained by examining the Soil map of study area, and the erosion process coefficients are classified into five categories, ranging from 0.12 (lower limit of the "Hard Soil, erosion resistant" class) to 0.31 (upper limit of the "soils without erosion resistance" class).

\section{Soil Protection Coefficient (Xa Factor)}

To determine the Xa-Factor values utilized by the EPM, Soil protection coefficient was estimated by the use of a modified NDVI (XaNDVI), based in the methodology proposed by zorn and komac 2008 (Chaaouan et al., 2013), $\mathrm{Xa}$-Factor is calculated using the following equation (4):

$$
\mathrm{X}_{\mathrm{a}}=\left(\mathrm{X}_{\mathrm{a}} \cdot \mathrm{NDVI}-0 \cdot 61\right) \cdot(-1 \cdot 15)
$$

The Soil protection coefficient (Xa) was estimated by the use of EPM Guide Table 2 (Gavrilovic, 1988). This model classifies land uses into 6 categories and evaluates the coefficient ' $\mathrm{Xa}$ ' from 0.1 (for high-density woodlands) to 1.0 (for badlands).

\section{The Coefficient of Slope (J-Factor)}

The coefficient of slope was calculated using a DEM (Digital Elevation Model) of the Souss basin area. A DEM with a resolution of $30 \mathrm{~m}$ was used to generate slope parameter through Raster Surface tools in ArcGIS. The slopes were re-classified into seven categories ranging from $0-5$ to $50 \%$. The mean values of each slope class were assigned in decimal system (Table 3 ) to determine the IFactor (Gavrilovic, 1988).

Table 2 EPM Soil protection coefficient values

\begin{tabular}{l|c}
\hline \multicolumn{1}{c|}{ Coefficient of Soil Cover } & Xa Factor \\
\hline Mixed and dense forest & $0.05-0.20$ \\
Thin forest with grove & $0.05-0.20$ \\
Coniferous forest with little grove, scarce & $0.20-0.40$ \\
bushes, bushy prairie & $0.40-0.60$ \\
Damaged forest and bushes, pasture & $0.60-0.80$ \\
Damaged pasture and cultivated land & $0.80-1.00$ \\
Areas without vegetal cover &
\end{tabular}

Table 3 Slope classes and the assigned I-facto for each map class, used in EPM model

\begin{tabular}{l|cc}
\hline \multicolumn{1}{c|}{ Slope class } & Slope $(\%)$ & I-factor \\
\hline 1 & $0-5$ & 0.025 \\
2 & $5-10$ & 0.075 \\
3 & $10-20$ & 0.150 \\
4 & $20-30$ & 0.250 \\
5 & $30-40$ & 0.350 \\
6 & $40-50$ & 0.450 \\
7 & $>50$ & 0.600 \\
\hline
\end{tabular}

\section{Erosion coefficient of watershed ( $\psi$-Factor)}

Coefficient $\varphi$ stands for the degree of expressed erosion processes in the basin, with its value ranging between 0.1 and 1(Gavrilovic, 1988) (Table 4),Data for estimating the soil resistance to erosion ( $\varphi$ factor) was obtained using the methodology proposed by Zorn and Komac (2008) (Chaaouan et al., 2013), $\varphi$ factor is calculated using the following equation (5):

$$
\psi=\sqrt{\frac{\mathrm{TM} 4}{\mathrm{Q}_{\max }}}
$$

Where TM4 band 4 of Landsat image 8, Qmax is the radiance maximum of band 4 , erosion coefficient in Souss basin ranging from 0.29 to 0.72 .

Table 4 EPM coefficient values of erosion coefficient

\begin{tabular}{l|c}
\hline \multicolumn{1}{c|}{ Coefficient of type and extent of erosion } & $\psi$ \\
\hline $\begin{array}{l}\text { Little erosion on watershed } \\
\text { Erosion in waterways on 20-50\% of the } \\
\text { catchment area }\end{array}$ & $0.10-0.20$ \\
$\begin{array}{l}\text { Erosion in rivers, gullies and alluvial } \\
\text { deposits, karstic erosion }\end{array}$ & $0.30-0.50$ \\
$50-80 \%$ of catchment area affected by & $0.60-0.70$ \\
surface erosion and landslides & $0.80-0.90$ \\
Whole watershed affected by erosion & $0.90-1.00$ \\
\hline
\end{tabular}

\section{Climatic Data}

Meteorological data for calculation of mean annual temperature and rainfall was obtained from 15 meteorological stations in Souss basin and imported into the ArcGIS environment. The spline interpolation method was used to generate a raster maps for this parameters.

\section{EPM Model}

The result of EPM calculation for erosion in the studied area is calculated using the equation (1). The results have been obtained from all gathered data and maps, such as soil erodibility map, soil protection map, slope map, erosion coefficient of watershed map, precipitation and temperature maps, The results show the spatial variations fact of the rate of erosion and sedimentation within the studied area, due to the spatial variation of the above mentioned factors, which must be taken into consideration in calculating erosion rate in the model.

The calculated soil loss for the EPM model varied from 0.02 to $181 \mathrm{~m}^{3} / \mathrm{km}^{2} /$ year and was classified from very low to moderate erosion (Figure 8). Approximately $87.84 \%$ of the total area ranged between low and very low potential soil losses, $12.15 \%$ of the surface was moderately. The erosion was high at the northeast area of the basin. 


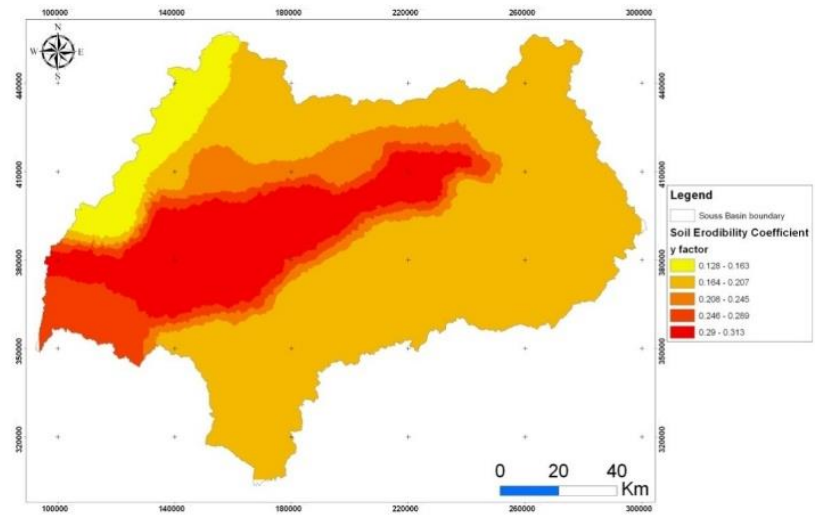

Figure 2 Soil Erodibility Coefficient map

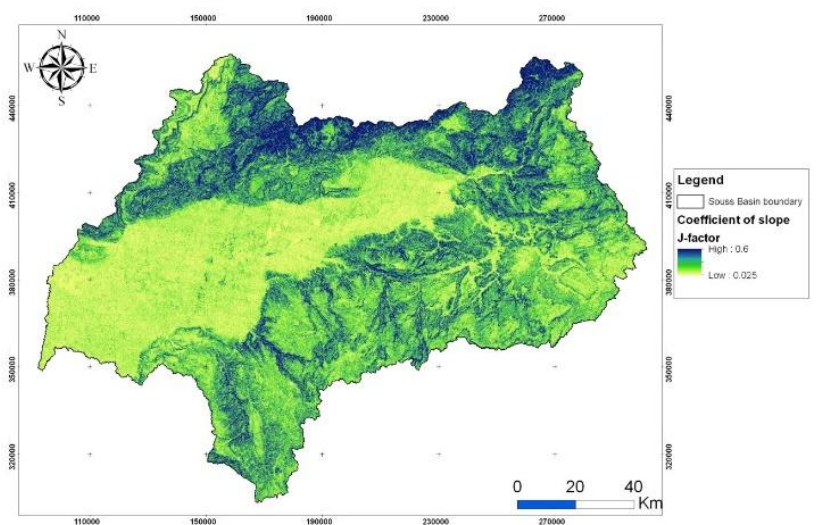

Figure 4 The coefficient of slope map

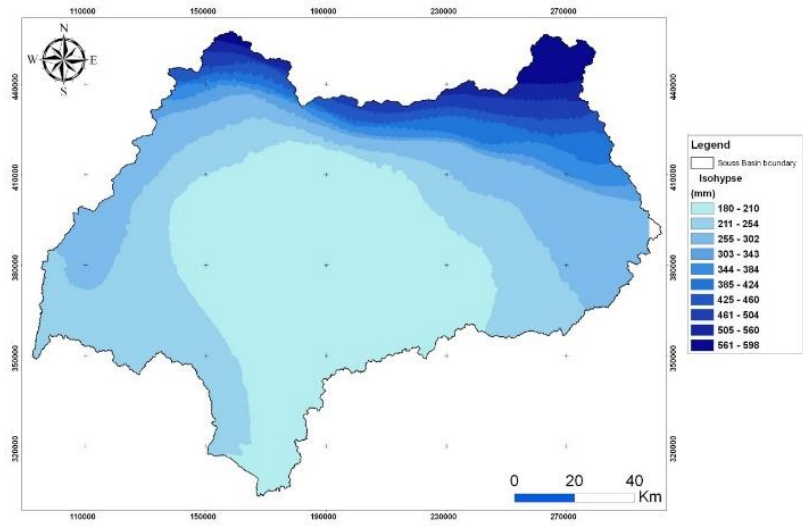

Figure 6 Isohypse map

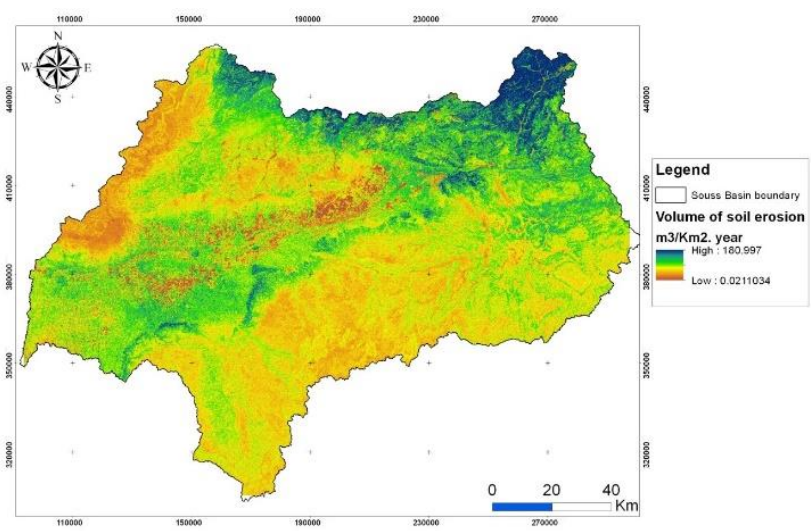

Figure 8 Erosion intensity map

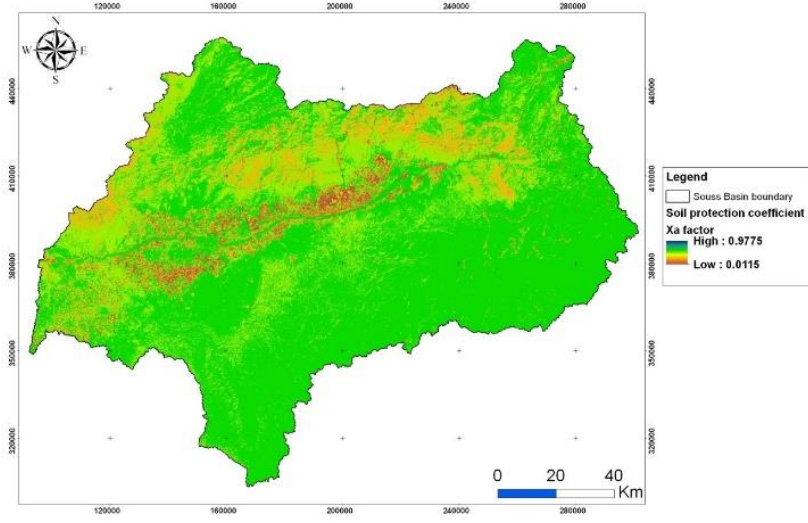

Figure 3 Soil protection coefficient map

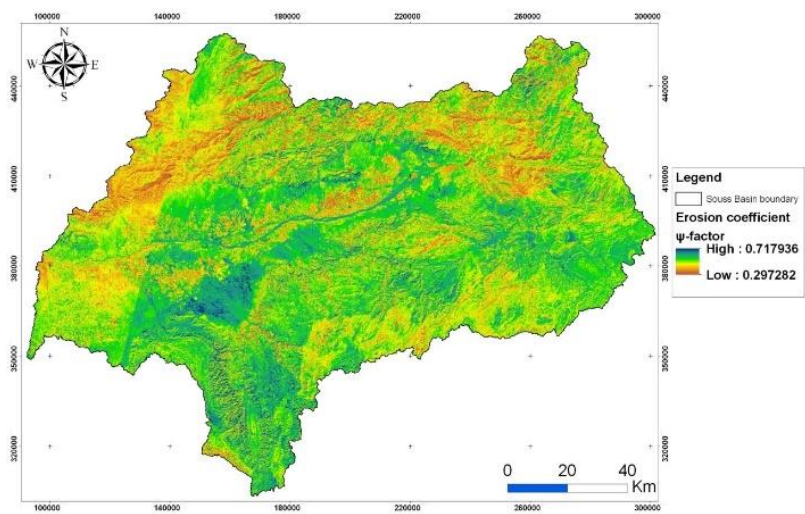

Figure 5 Erosion coefficient map

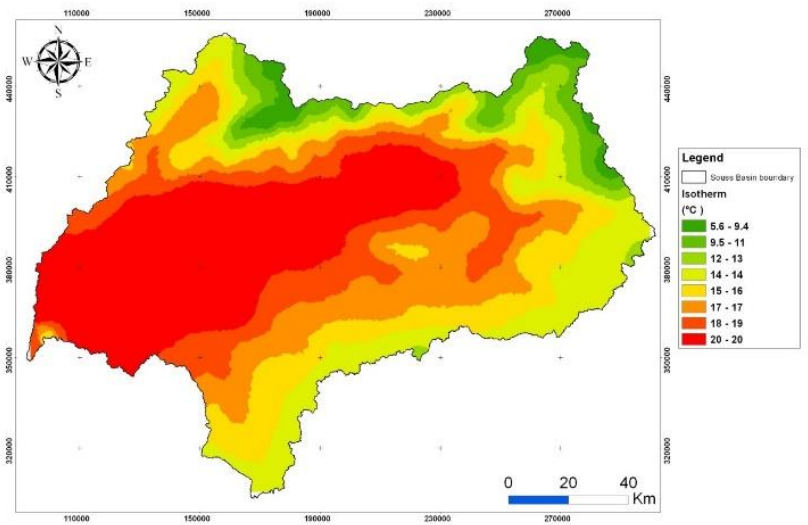

Figure 7 Isotherm map

\section{Conclusions}

The main objective of this study is to apply the EPM model to the Souss basin, in order to estimate soil erosion and investigate its spatial distribution, The present study showed that EPM (erosion potential model), with the aid of remote sensing and GIS techniques, could be useful tool in the identification and analysis of soil loss in areas such as Souss basin area. Factors as soil erodibility, soil protection, slope, temperature and rainfall are important to control the erosion process. The results suggest a soil loss varied from 0.02 to $181 \mathrm{~m}^{3} / \mathrm{km}^{2} /$ year. Erosion mapping through EPM method showed to be a useful tool for environmental monitoring and water resources management, which could provide satisfactory results when jointly used. 


\section{References}

Ali SS, Sarkawt GS, Nadhir A, Sven K. 2016. GIS Based Soil Erosion Estimation Using EPM Method, Garmiyan Area, Kurdistan Region, Iraq. Journal of Civil Engineering and Architecture.,10 . 291-308. https://doi.org/10.17265/19347359/2016.03.004.

Chaaouan J, Faleh A, Sadiki A, Mesrar H. 2013. Télédétection, SIG et Modélisation de l' Érosion Hydrique Dans Le Bassin Versant de 1' Oued Amzaz, Rif Central. Revue Francaise D E Teledetection Photogrammetriede ,Universit Sidi Mohamed Ben Abdellah,.

Chadli K. 2016. Estimation of Soil Loss Using RUSLE Model for Sebou Watershed ( Morocco ). Modeling Earth Systems and Environment, 1-10. https://doi.org/10.1007/s40808-0160105-y.

Choukr-Allah R, Ragab R, Bouchaou L, Dami B. 2017. The Souss-Massa River Basin, Morocco. The Handbook of Environmental Chemistry 53. https://doi.org/10.1007/978-3319-51131-3.

Dragičević N, Barbara K, Nevenka O. 2016. A Review of the Gavrilović Method ( Erosion Potential Method ) Application" 68: 715-25. https://doi.org/10.14256/JCE.1602.2016.

Efthimiou N, Lykoudi E. 2016. SOIL EROSION ESTIMATION USING THE EPM. Bulletin of the Geological Society of Greece 50: 305-14.

Elaloui A, Chakib M, Ahmed F, Maimouni S. 2017. USLE-Based Assessment of Soil Erosion by Water in the Watershed Upstream Tessaoute ( Central High Atlas , Morocco ). Modeling Earth Systems and Environment. https://doi.org/10.1007/s40808-017-0340-x.
FAO/UNEP. 1994. Land Degradation in South Asia: Its Severity Causes and Effects upon the People. FAO and UNEP Project,Rome.

Gavrilovic, Z. 1988. The Use of an Empirical Method for Calculating Sediment Production and Transport in Unsuited or Torrential Streams. International Con. for Review Regime, 411-22.

Noori H, Seyed M, Barat M. 2016. International Soil and Water Conservation Research Assessment of Sediment Yield Using RS and GIS at Two Sub-Basins of Dez Watershed, Iran. International Soil and Water Conservation Research, 0-1. https://doi.org/10.1016/j.iswcr.2016.06.001.

Patil RJ. 2018. Spatial Techniques for Soil Erosion Estimation Remote Sensing and GIS Approach. https://doi.org/https:// doi.org/10.1007/978-3-319-74286-1.

Prasannakumar V, Shiny R, Geetha N, Vijith H. 2015. Approach : A Case Study of Siruvani River, https://doi.org/10.1007 /s12665-011-0913-3.

Reza M, Mansouri D, Bagherzadeh A. 2012. Evaluation of Sediment Yield in PSIAC and MPSIAC Models by Using GIS at Toroq Watershed, Northeast of Iran. 6 (1): 83-94. https://doi.org/10.1007/s11707-011-0189-7.

Wischmeier W.H, Smith D.D. 1978. Predicting Rainfall Erosion Losses. A Guide to Conservation Planning. The USDA A

Yousefi S, Somayeh M. 2014. An Estimation of Sediment by Using Erosion Potential Method and Case Study of Ilam Province , Iran, Geodynamics Research International Bulletin(GRIB), Vol. (II)- No. 02, SN:05, Spring Issue

Zemljic M. 1971. Calcul Du Debit Solide - Evaluation de La Vegetation Comme Un Des Facteurs Antierosifs. International Symposium Interpraevent. Villach,Austria. 